\title{
Nucleotide Transition 390C-T in the Wilms' Tumor 1 Gene: A Risk Factor of Hypospadias?
}

\author{
Gergely Buglyóo ${ }^{a^{*}} \quad$ Ágnes Magyar ${ }^{b^{*}} \quad$ Sándor Biróa \\ István Csízy ${ }^{\mathrm{b}}$ Dániel Beyer ${ }^{\mathrm{a}} \quad$ Kinga Molnár $^{\mathrm{a}} \quad$ Éva Oláh $^{\mathrm{b}}$

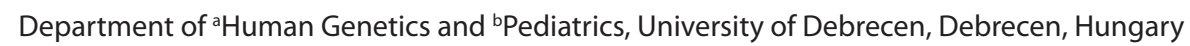 \\ *These authors contributed equally to the manuscript.
}

\section{Key Words}

WT1 gene $\cdot$ WTIP gene $\cdot$ Rs2234583 $\cdot$ Hypospadias

\begin{abstract}
Introduction: The gene Wilms' tumor 1 (WT1) encodes a unique transcription factor. Its defects are known to cause a wide range of complex genitourinary malformations and may contribute to non-syndromic forms of hypospadias. Materials and Methods: We performed WT1 mutation analysis and copy number analysis of WT1-interacting protein in 13 Hungarian patients diagnosed with isolated hypospadias. Results: Sequencing of WT1 revealed a high frequency of heterozygosity for transition 390C-T (5 heterozygotes out of 13 patients, including 2 brothers). WT1-interacting protein had a normal copy number in all patients. Conclusion: $\mathrm{Nu}$ cleotide substitution 390C-T may play a role in the pathogenesis of non-syndromic hypospadias. The genotype-phenotype correlation should be confirmed by a larger-scale analysis.

Copyright $\odot 2016$ S. Karger AG, Basel
\end{abstract}

\section{Introduction}

Hypospadias is a common disorder of the male external genitalia with an incidence estimated at 2-43 per 10,000 live births $[1,2]$. It may occur as isolated, non -syndromic hypospadias or as part of a complex genitourinary malformation syndrome. Non-syndromic cases are generally considered to be multifactorial in their or-

\section{KARGER}

Fax +4161306 1234

E-Mail karger@karger.com

www.karger.com
(C) 2016 S. Karger AG, Basel

Accessible online at: www.karger.com/cur igin, but familial aggregation has been reported, encouraging mutation analyses that supported the argument for a strong genetic component in their pathogenesis [3-5].

Among the many genes suspected to play a role in the normal embryonic development of external genitalia, Wilms' tumor 1 (WT1) is traditionally considered as an important regulator of early stages, as its mutations often cause severe, syndromic cases of hypospadias [6]. However, alterations in the sequence of exon 1 and 2 have also been suggested to be responsible for isolated hypospadias [7].

WT1 encodes a unique transcription factor that may up- or down-regulate the activity of the same promoters depending on tissue-specific cofactors binding to the WT1 protein [8]. One such cofactor is WT1-interacting protein (WTIP) that may contribute to the dysregulation of podocyte phenotype by shuttling into the nucleus upon injury [9]. Apart from the protein's putative role in kidney function, haploinsufficiency of WTIP has been suggested as a possible cause of hypospadias [10].

We hereby report findings obtained by WT1 mutation analysis and WTIP copy number detection of 13 Hungarian patients with hypospadias.

\section{Materials and Methods}

Our sample consisted of 13 children born in Hungary, aged from 7 months to 13 years (median age 6 years) presented with isolated hypospadias. Written informed consent was obtained 
Table 1. Non-syndromic hypospadias patients enrolled in WT1 mutation analysis and WTIP copy number detection. Patients 5,6 and 7 are siblings, as well as 12 and 13 (marked by * and **, respectively)

\begin{tabular}{clllll}
\hline Patient & Age & Karyotype & Type of hypospadias & Genotype (WT1 390C-T) & WTIP copy number \\
\hline 1 & 3 years & $46, \mathrm{XY}$ & coronal & $\mathrm{C} / \mathrm{C}$ & 2 \\
2 & 6 years & $46, \mathrm{XY}$ & penoscrotal & $\mathrm{C} / \mathrm{C}$ & 2 \\
3 & 6 years & $46, \mathrm{XY}$ & penoscrotal & $\mathrm{C}$ & 2 \\
4 & 5 years & $46, \mathrm{XY}$ & penile & $\mathrm{C}$ & 2 \\
$5 *$ & 2 years & $46, \mathrm{XY}$ & subcoronal & $\mathrm{C}$ & 2 \\
$6 *$ & 13 years & $46, \mathrm{XY}$ & coronal & $\mathrm{C}$ & 2 \\
$7 *$ & 11 years & $46, \mathrm{XY}$ & glandular & $\mathrm{C}$ & \\
8 & 8 years & $46, \mathrm{XY}$ & coronal & $\mathrm{C} / \mathrm{T}$ & 2 \\
9 & 6 years & $46, \mathrm{XY}$ & coronal & $\mathrm{C} / \mathrm{C}$ & 2 \\
10 & 7 months & $46, \mathrm{XY}$ & penile & $\mathrm{C} / \mathrm{C}$ & \\
11 & 1 year & $46, \mathrm{XY}$ & coronal & $\mathrm{C} / \mathrm{T}$ & 2 \\
$12^{* *}$ & 7 years & $46, \mathrm{XY}$ & penile & $\mathrm{C} / \mathrm{T}$ & 2 \\
$13 *$ & 5 years & $46, \mathrm{XY}$ & subcoronal & \\
\hline
\end{tabular}

from the parents of all patients according to the Declaration of Helsinki. Patients' birth weight ranged from 2,150 to $4,350 \mathrm{~g}$ (median 2,550 g), while gestational age at birth ranged from 34 to 41 weeks (median 36 weeks). A summary of all enrolled cases including the location of the urethral meatus and our findings can be seen in table 1 . We studied 1 glandular, 5 coronal, 2 subcoronal, 3 penile and 2 penoscrotal cases of hypospadias. Our sample included 2 families, one with 2 and one with 3 brothers all affected by the disease - these should be considered separately from sporadic forms of the disease (table 1 ).

We extracted DNA from the samples using GenElute Blood Genomic DNA Kits (by SIGMA), used a traditional PCR to amplify a region of exon 1 of the WT1 gene that seemed the most relevant from the literature (5'-TTCGGCTTACGGGTCGTTG-3' as forward and 5'-CGCTTCCGCTATCCTCACG-3' as reverse primer), and sequenced the PCR products.

We also analyzed WTIP copy number in the samples using an Applied Biosystems 7500 Real Time PCR System and copy number assays provided by Applied Biosystems aimed at the target gene WTIP (product ID: Hs04008735_cn) and a control gene RNase P ("Taqman Copy Number Reference Assay, RNase P, Human"). The software CopyCaller (version 1.0) was used to assess copy number variations in the target gene based on slight differences between registered qRT-PCR plots.

\section{Results}

Sequencing WT1 exon 1 in all patients, the only variation we observed was the nucleotide transition 390C-T. The minor $(\mathrm{T})$ allele was found in heterozygous form in 5 cases of non-syndromic hypospadias: 3 with a coronal, 1 with a subcoronal and 1 with a penile manifestation (table 1). In 3 brothers showing hypospadias, the transition was found in one but absent in 2 sibs, raising the possibility of a more influential monogenic defect in the background, while in the other observed family, both brothers with hypospadias showed the 390C-T transition, which might suggest a possible role by the allele in the pathogenesis.

WTIP copy number in DNA samples obtained from the same set of patients did not show any variations (table $1)$.

\section{Discussion}

The $\mathrm{C}-\mathrm{T}$ transition we found in the WT1 gene at position 390 was originally reported by Wang et al. [7]. They observed it in 2 of 90 Chinese non-syndromic hypospadias patients, and also reported two more mutations: a $\mathrm{G}-\mathrm{A}$ transition in exon 1 and a $\mathrm{C}-\mathrm{T}$ transition in exon 2 , each one detected in a single patient. Overall, they found heterozygous sequence alterations of the WT1 gene in 4 of 90 patients. At that time, little was known about the worldwide frequency of transition 390C-T.

Based on exome and whole genome sequencing data made available during recent years, the $\mathrm{T}$ allele at position 390 is frequent enough to be considered as a polymorphism (rs2234583) in most populations: it has a global frequency of 7.77 percent according to the latest build of the dbSNP database [11]. Its frequency is lower in Europe (3.33-7.26\%), high in Africa (27.5-32.75\%) and very low in East Asia (0.79\%). The T allele was not observed in any of the studied 366 unrelated Chinese individuals without hypospadias [7, 11], suggesting that in the Chinese population (and probably some others) this 
nucleotide transition should be considered as a mutation rather than a polymorphism on the basis of its rarity.

Using a traditional PCR-based approach, we had to specify a narrow genomic region to study and did not have access to the data output of whole-genome sequencing methods. Still, our results obtained by WT1 exon 1 sequencing in non-syndromic hypospadias patients (presented in table 1) raise some questions. Given how rare the 390T allele is in WT1 gene copies of healthy European individuals, our findings seem to support the observation made by Wang et al. [7] despite the small sample size - it needs to be confirmed whether the variant is indeed a risk factor for non-syndromic hypospadias. Unfortunately, WT1 SNP rs2234583 was not included in either one of the recent large-scale association studies aiming to reveal genetic polymorphisms in the background of isolated hypospadias in Californian and Northern European populations $[12,13]$.

Based on their own patients and further cases from the literature, Gana et al. [10] attempted to assign phenotypic features of the $19 q 13.11$ deletion syndrome to the haploinsufficiency of individual genes in the region. They argued that hypospadias (when present) is most likely due to the heterozygous deletion of WTIP. As multiple deletions of different extent had been reported in region $19 q 13.11$ [14], we decided to investigate if WTIP may suffer a microdeletion leaving other genes in the region intact and causing hypospadias, which might be more common than a complete form of the $19 \mathrm{q} 13.11$ deletion syndrome. Having obtained a negative result from a small sample of 13 patients certainly cannot be considered as conclusive, but it does not seem to support that hypothesis. When studying the putative pathogenic role of WTIP haploinsufficiency proposed by Gana et al. [10], it should be noted that the protein may have functions in addition to regulating genitourinary development, such as epithelial ciliogenesis [15] or retinoic acid signaling in the epicardium [16], so a deficiency involving WTIP might not be a likely cause in a case of isolated hypospadias.

According to certain authors [6], a reason why the role of genetic factors in the background of hypospadias is so difficult to determine is that many of them have larger influences in combination with other factors, due to gene-gene and gene-environment interactions. Such may be the case for WT1 polymorphism rs2234583, which shows a surprising level of geographical variation in allele frequencies, raising the possibility that its minor allele might be disease-associated in certain populations but not in others [17]. While the polymorphism has been completely overlooked by genome-wide association studies, smaller-scale evidence available in the literature and gained from our own contribution based on an Eastern European population may imply a role in non-syndromic hypospadias, and we argue that it would justify further, larger-scale investigations.

\section{References}

1 Bergman JE, Loane M, Vrijheid M, Pierini A, Nijman RJ, Addor MC, Barisic I, Béres J, Braz P, Budd J, Delaney V, Gatt M, Khoshnood B, Klungsøyr K, Martos C, Mullaney C, Nelen V, Neville AJ, O'Mahony M, Queisser-Luft A, Randrianaivo H, Rissmann A, Rounding C, Tucker D, Wellesley D, Zymak-Zakutnia N, Bakker MK, de Walle HE: Epidemiology of hypospadias in Europe: a registry-based study. World J Urol 2015;33:2159-2167.

2 Paulozzi LJ: International trends in rates of hypospadias and cryptorchidism. Environ Health Perspect 1999;107:297-302.

$3 \mathrm{Wu}$ WH, Chuang JH, Ting YC, Lee SY, Hsieh CS: Developmental anomalies and disabilities associated with hypospadias. J Urol 2002;168:229-232.
4 Schnack TH, Zdravkovic S, Myrup C, Westergaard T, Christensen K, Wohlfahrt J, Melbye M: Familial aggregation of hypospadias: a cohort study. Am J Epidemiol 2008;167: 251-256.

5 Kon M, Suzuki E, Dung VC, Hasegawa Y, Mitsui T, Muroya K, Ueoka K, Igarashi N, Nagasaki K, Oto Y, Hamajima T, Yoshino K, Igarashi M, Kato-Fukui Y, Nakabayashi K, Hayashi K, Hata K, Matsubara Y, Moriya K, Ogata T, Nonomura K, Fukami M: Molecular basis of non-syndromic hypospadias: systematic mutation screening and genome-wide copy-number analysis of 62 patients. Hum Reprod 2015;30:499-506.

6 Van der Zanden LF, van Rooij IA, Feitz WF, Franke B, Knoers NV, Roeleveld N: Aetiology of hypospadias: a systematic review of genes and environment. Hum Reprod Update 2012;18:260-283.
7 Wang Y, Li Q, Xu J, Liu Q, Wang W, Lin Y, Ma F, Chen T, Li S, Shen Y: Mutation analysis of five candidate genes in Chinese patients with hypospadias. Eur J Hum Genet 2004; 12:706-712.

8 Essafi A, Webb A, Berry RL, Slight J, Burn SF, Spraggon L, Velecela V, Martinez-Estrada OM, Wiltshire JH, Roberts SG, Brownstein D, Davies JA, Hastie ND, Hohenstein P: A wt1-controlled chromatin switching mechanism underpins tissue-specific wnt4 activation and repression. Dev Cell 2011;21:559574.

9 Srichai MB, Konieczkowski M, Padiyar A, Konieczkowski DJ, Mukherjee A, Hayden PS, Kamat S, El-Meanawy MA, Khan S, Mundel P, Lee SB, Bruggeman LA, Schelling JR, Sedor JR: A WT1 co-regulator controls podocyte phenotype by shuttling between adhesion structures and nucleus. J Biol Chem 2004;279:14398-14408. 
10 Gana S, Veggiotti P, Sciacca G, Fedeli C, Bersano A, Micieli G, Maghnie M, Ciccone R, Rossi E, Plunkett K, Bi W, Sutton VR, Zuffardi O: 19q13.11 cryptic deletion: description of two new cases and indication for a role of WTIP haploinsufficiency in hypospadias. Eur J Hum Genet 2012;20:852-856.

11 Database of Single Nucleotide Polymorphisms (dbSNP). Bethesda (MD): National Center for Biotechnology Information, National Library of Medicine. (dbSNP Build ID: 148, released in 2016). Available from: http://www.ncbi.nlm.nih.gov/SNP/

12 Carmichael SL, Ma C, Choudhry S, Lammer EJ, Witte JS, Shaw GM: Hypospadias and genes related to genital tubercle and early urethral development. J Urol 2013;190:18841892.
13 Geller F, Feenstra B, Carstensen L, Pers TH, van Rooij IA, Körberg IB, Choudhry S, Karjalainen JM, Schnack TH, Hollegaard MV, Feitz WF, Roeleveld N, Hougaard DM, Hirschhorn JN, Franke L, Baskin LS, Nordenskjöld A, van der Zanden LF, Melbye M: Genome-wide association analyses identify variants in developmental genes associated with hypospadias. Nat Genet 2014;46:957963.

14 Malan V, Raoul O, Firth HV, Royer G, Turleau C, Bernheim A, Willatt L, Munnich A, Vekemans M, Lyonnet S, Cormier-Daire V, Colleaux L: 19q13.11 deletion syndrome: a novel clinically recognisable genetic condition identified by array comparative genomic hybridisation. J Med Genet 2009;46:635640.
15 Chu CW, Ossipova O, Ioannou A, Sokol SY: Prickle3 synergizes with Wtip to regulate basal body organization and cilia growth. Sci Rep 2016;6:24104.

16 Khan FF, Li Y, Balyan A, Wang QT: WTIP interacts with ASXL2 and blocks ASXL2mediated activation of retinoic acid signaling. Biochem Biophys Res Commun 2014;451: 101-106.

17 Cross DS, Ivacic LC, Stefanski EL, McCarty CA: Population based allele frequencies of disease associated polymorphisms in the Personalized Medicine Research Project. BMC Genet 2010;11:51. 